\title{
Production of Cloned Korean Native Pig by Somatic Cell Nuclear Transfer
}

\author{
In-Sul Hwang ${ }^{1}$, Dae-Jin Kwon ${ }^{1}$, Keun Bong $\mathrm{Oh}^{1}{ }^{1}$, Sun-A Ock ${ }^{1}$, Hak-Jae Chung ${ }^{1}$, In-Cheol Cho ${ }^{2}$, \\ Jeong-Woong Lee ${ }^{3}$, Gi-Sun Im $^{1}$ and ${ }^{\dagger}$ Seongsoo Hwang ${ }^{1}$ \\ ${ }^{1}$ Animal Biotechnology Division, National Institute of Animal Science, Wanju 565-851, Korea \\ ${ }^{2}$ Subtropical Livestock Research Institute, NIAS, Jeju 690-150, Korea \\ ${ }^{3}$ Functional Genomics Research Center, KRIBB, Daejeon 305-806, Korea
}

\begin{abstract}
The Korean native pig (KNP) have been considered as animal models for animal biotechnology research because of their relatively small body size and their presumably highly inbred status due to the closed breeding program. However, little is reported about the use of KNP for animal biotechnology researches. This study was performed to establish the somatic cell nuclear transfer (SCNT) protocol for the production of swine leukocyte antigens (SLA) homotype-defined SCNT KNP. The ear fibroblast cells originated from KNP were cultured and used as donor cell. After thawing, the donor cells were cultured for 1 hour with $15 \mu \mathrm{M}$ roscovitine prior to the nuclear transfer. The numbers of reconstructed and parthenogenetic embryos transferred were $98 \pm 35.2$ and $145 \pm 11.2$, respectively. The pregnancy and delivery rate were $3 / 5(60 \%)$ and $2 / 5$ (40\%). One healthy SLA homotype-defined SCNT KNP was successfully generated. The recipient-based individual cloning efficiency ranged from 0.65 to $1.08 \%$. Taken together, it can be postulated that the methodological establishment of the production of SLA homotype-defined cloned KNP can be applied to the generation of transgenic cloned KNP as model animals for human disease and xenotransplantation researches.
\end{abstract}

Key words : Korean native pig, Swine leukocyte antigens, Somatic cell nuclear transfer, Animal model, Cloning efficiency

\section{INTRODUCTION}

Somatic cell nuclear transfer (SCNT) can potentially be used to produce various species such as sheep (Wilmut et al., 1997), cattle (Kato et al., 1998), goat (Baguish et al., 1999), and pig (Betthauser et al., 2000; Onishi et al., 2000; Polejaeva et al., 2000) or unlimited animal clones that naturally exhibit high-performance or other desirable traits. Because of their similar anatomy and physiology, pig have become a progressively more important large animal model for organ transplantation research relating to, for example, immunological rejection, effectiveness of immunosuppressive drugs on tolerance, and development of induction protocols for long-term tolerance (Dehoux \& Gianello, 2007; Zhao et al., 2009; Ahn et al., 2011; Hanekamp et al., 2011).

Especially, miniature pig also shares many physiological similarities with humans and offers several breeding, such as Yucatan, Hanford, Sinclair, and Massachusetts General Hospital (MGH), and handling advantages, making it an optimal species for preclinical and biomedical experimentation (Yeom et al., 2012; Kim et al., 2013). The Korean native pig (KNP) have been considered as animal models for

\footnotetext{
Manuscript received 5 April 2015, Received in revised form 12 April 2015, Accepted 20 May 2015

† Corresponding Author : Seongsoo Hwang, Animal Biotechnology Division, NIAS, RDA, Wanju 565-851, Korea. Tel. : +82-63-238-7253, Fax : +82-63238-7297, E-mail : hwangss@korea.kr

This is an Open Access article distributed under the terms of the Creative Commons Attribution Non-Commercial License (http:// creativecommons.org/licenses/by-nc/3.0) which permits unrestricted non-commercial use, distribution, and reproduction in any medium, provided the original work is properly cited.
} 
transplantation and xenotransplantation research because of their relatively small body size (less than $70 \mathrm{~kg}$ at maturity) and their presumably highly inbred status due to the closed breeding program since 1986 (Kim et al., 2002).

Swine leukocyte antigens (SLAs) are the major histocompatibility complex (MHC) molecules of swine, consist of a group of genes designated as MHC systems. SLAs have been repeatedly implicated in swine disease resistance and vaccine response and play very important roles in the adaptive immune system (Chardon et al., 2000; Kelley et al., 2005). In using pigs as large animal models for human transplantation and as potential xenograft donors, the SLA antigens are important targets for allo- and xeno-immunological recognition and can be directly recognized by various human immune cell subsets (Shishido et al., 1997; Kwiatkowski et al., 1999).

In KNP, the three functional SLA class I loci, SLA-1, SLA-2 and SLA-3, have been reported (Woo et al., 2005, 2006; Kim et al., 2006). After that, two important SLA class II genes, DQB1 and DRB1, were additionally identified in KNP (Woo et al., 2007). Based on the analysis systems, we have established homotype-defined 5 SLAs (DQB1, DRB1, SLA-1, SLA-2, and SLA-3) KNP herd (Cho et al., 2010). This study was performed to establish the SCNT protocol for the production of swine leukocyte antigens (SLA) homotype-defined SCNT KNP.

\section{MATERIALS \& METHODS}

\section{General information}

Our study protocol and standard operating procedures for the treatments of the pigs used were reviewed and approved by the Institutional Animal Care and Use Committee of the National Institute of Animal Science, RDA (Approval number: NIAS2015-670, D-grade).

\section{Ear fibroblast cell culture}

Ear tissue originated from homotype-defined SLA (DQB1, DRB1, SLA1, SLA2, and SLA3) Korean native pig (KNP, Subtropical Livestock Research Institute, NIAS, Jeju) (unpublished data). Ear fibroblasts obtained from the KNP were cultured in Dulbecco's modified Eagle medium (WelGene Inc., Korea) containing 20\% FBS, $1 \mathrm{mM}$ of nonessential amino acid (GIBCO), $1 \mathrm{mM}$ of Sodium Pyruvate (WelGene, Korea), $55 \mu \mathrm{M}$ of $\beta$-mercaptoethanol (GIBCO), and $1 \%$ antibiotics $(100 \mathrm{U} / \mathrm{mL}$ penicillin and $100 \mu \mathrm{g} / \mathrm{mL}$ streptomycin; $\mathrm{GIBCO}$ ) at $37^{\circ} \mathrm{C}$ in an atmosphere of $5 \%$ $\mathrm{CO}_{2}$ in air (Fig. 1). When the cells were confluence in the culture dish, the cells were detached and aliquoted $(5 \times$ $10^{3} / \mathrm{mL} /$ tube) for nuclear transfer.

\section{In vitro maturation}

In vitro maturation of porcine immature follicular oocytes was performed as follows with slightly modifications (Kim et al., 2005). Porcine ovaries were obtained from a local slaughterhouse (Nonghyup Moguchon, Gimje, South Korea) and transported to the laboratory at $30-35^{\circ} \mathrm{C}$. Cumulusoocyte complexes (COCs) were collected and washed in Tyrode's lactate-Hepes containing $0.1 \%(\mathrm{w} / \mathrm{v})$ polyvinyl

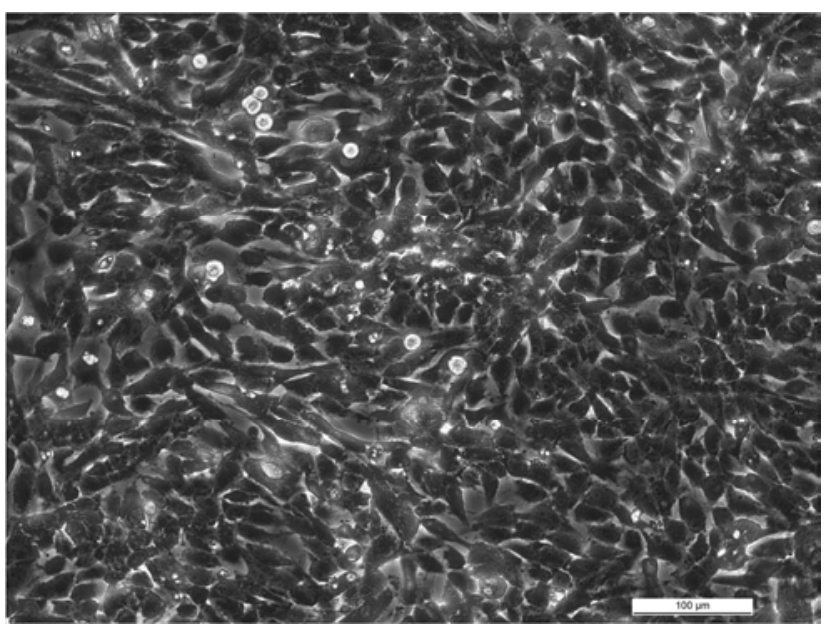

Fig. 1. Cell culture of homotype-defined SLAs KNP. The cells were originated from five functional SLAs (DQB1, DRB1, SLA-1, SLA-2, and SLA-3) homotype-defined KNP and used as donor cell. 
alcohol (PVA). Oocytes with several layers of cumulus cells were selected and washed three times in TCM-199 (GIBCO) supplemented with 0.1\% PVA (w/v), $3.05 \mathrm{mM}$ D-glucose, $0.91 \mathrm{mM}$ sodium pyruvate, $0.57 \mathrm{mM}$ cysteine, $0.5 \mu \mathrm{g} / \mathrm{mL}$ luteinizing hormone, $0.5 \mu \mathrm{g} / \mathrm{mL}$ follicle stimulating hormone, $10 \mathrm{ng} / \mathrm{mL}$ epidermal growth factor, $10 \%$ porcine follicular fluid (pFF), $75 \mu \mathrm{g} / \mathrm{mL}$ penicillin $\mathrm{G}$, and $50 \mu \mathrm{g} /$ $\mathrm{mL}$ streptomycin (maturation medium). For in vitro maturation, 50 COCs were transferred into $500 \mu \mathrm{L}$ of maturation medium in a four-well dish (Nunc, Roskilde, Denmark). The oocytes were matured for $40 \mathrm{~h}$ at $38.5^{\circ} \mathrm{C}$ under $5 \% \mathrm{CO}_{2}$ in air.

\section{Nuclear transfer procedure}

Somatic cell nuclear transfer was performed as follows (Hwang et al., 2013). Briefly, matured oocytes were enucleated by aspirating the first polar body and metaphase II chromosomes and a small amount of surrounding cytoplasm in manipulation medium supplemented with $5 \mu \mathrm{g} / \mathrm{mL}$ cytochalasin B. The freshly-thawed donor cells treated with Roscovitine were inserted into perivitelline space. The karyoplast-cytoplast complexes were placed into $0.2-\mathrm{mm}$ diameter wire electrodes ( $1 \mathrm{~mm}$ apart) of a fusion chamber covered with $0.3 \mathrm{M}$ mannitol solution containing $0.1 \mathrm{mM}$ $\mathrm{MgSO}_{4}, 1.0 \mathrm{mM} \mathrm{CaCl} 2$ and $0.5 \mathrm{mM}$ Hepes. For reconstructions, two DC pulses (1-sec interval) of $1.5 \mathrm{kV} / \mathrm{cm}$ were applied for $30 \mu \mathrm{s}$ using an Electro-Cell fusion (Fujihira Industry, Japan).

\section{Embryo transfer and parturition}

Immediately after confirmation of fusion using a stereoscope, the reconstructed embryos were transferred into both oviducts of the surrogate (Landrace) on the same day or 1 day after the onset of estrus. Pregnancy was diagnosed on day 28 after ET and then was checked regularly every week by ultrasound examination. The TG cloned piglets were delivered by natural parturition or Caesarean section.

\section{RESULTS}

A summary of the pregnancy and delivery rates of KNP is shown in Table 1. The mean number of the transferred embryos was $243 \pm 25.4$ per surrogate. Among them, the number of the embryos transferred was $98 \pm 35.2$ in cloned embryos and $145 \pm 11.2$ in parthenogenetic embryos, respectively. Among 5 surrogates, three were pregnant (3/5) and two were ongoing to full-term $(2 / 5)$.

Table 2 shows the individual productivity of homotypedefined SLA cloned KNP. The total number of delivered cloned pigs was 3 ( 1 alive, 1 mummy, and 1 died after birth) (Fig. 2). The recipient-based individual cloning efficiency was ranged from $0.65 \%$ to $1.08 \%$.

\section{DISCUSSION}

Cloned embryos have shown high embryonic mortality than normal embryos because of complex procedure of somatic cell nuclear transfer (Lai et al., 2002). Such a high embryonic mortality is mainly due to the asynchronous development of embryos in the maternal uterus and inappropriate interactions between the maternal uterus and developing embryos during implantation and plancentation (Pope, 1994). In pig, the blastocysts undergo dramatic morphological changes, developing from 11 to $50 \mathrm{~mm}$

\section{Table 1. Pregnancy and delivery rate}

\begin{tabular}{cccc}
\hline \hline \multicolumn{2}{c}{$\begin{array}{c}\text { No. of } \\
\text { embryos transferred }\end{array}$} & \multicolumn{2}{c}{$\begin{array}{c}\text { No. of } \\
\text { surrogates }\end{array}$} \\
\hline NT & Parthenotes & Pregnancy* & Delivery** \\
\hline $97.6 \pm 35.2$ & $145 \pm 11.2$ & $3 / 5$ & $2 / 5$ \\
\hline
\end{tabular}

* Pregnancy was confirmed by gestation sac formation using ultrasound examination at 28 days after embryo transfer. Data were expressed as mean \pm SD.

** No. of delivered / No. of pregnancy (including the piglets died within 1 day) 
Table 2. Full term development of KNP cloned piglets

\begin{tabular}{ccccc}
\hline \multirow{2}{*}{ Surrogate } & \multirow{2}{*}{ Delivery status } & \multicolumn{2}{c}{ No. of piglets } & \multirow{2}{*}{ Cloning efficiency** } \\
\cline { 3 - 4 } & $114^{*}$ & At birth & $0.65(1 / 155)$ \\
\hline 1 & No pregnancy & - & 1 & $-(0 / 86)$ \\
3 & No pregnancy & & & $-(0 / 95)$ \\
4 & $125^{*}$ & Mummy & 1 & $1.69(1 / 59)$ \\
5 & $117^{*}$ & Normal & 1 & $1.08(1 / 93)$ \\
\hline & Total & 12 & &
\end{tabular}

* Pregnancy periods after transfer of KNP cloned embryos

** No. of piglets born/No. of TG cloned embryos transferred

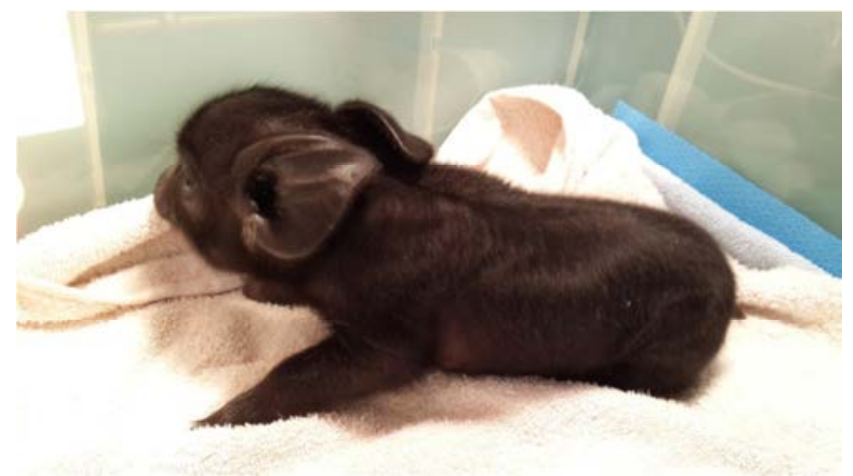

Fig. 2. Production of homotype-defined SLAs cloned KNP. The five functional SLAs (DQB1, DRB1, SLA-1, SLA-2, and SLA-3) homotype-defined cloned KNP was delivered by Caesarean section (C-sec) at 117 days after embryo transfer.

tubular structure into $100 \mathrm{~mm}$ filamentous structure during gestation days 10-15 (Giesert et al., 1982). These critical changes coincide with the synthesis and release of fetalmaternal recognition signals (estrogen) and cytokines required for the establishment of pregnancy (Bowen \& Burghardt, 2000; Spencer \& Bazer. 2004; Bazer et al., 2009).

To improve the cloning efficiency, we transferred the reconstructed embryos into the oviduct of the surrogates with parthenogenetic embryos simultaneously. Co-transfer of cloned embryos with parthenogenetic embryos with may be one of the methods to enhance the signal for maternal recognition, because fetal development and implantation of parthenotes can be happened like normal fetuses until gestation days 31 and then die shortly afterwards in pigs (Zhu et al., 2000, 2003; Han et al., 2013). Normal fetal development of parthenogenetic fetus originated from parthenogenetic embryos may affect positively to the uterine environment of surrogates and help to implantation of cloned fetuses during early pregnancy period. Like the previous results, we had transferred parthenogenetic embryos and retrieved the normal morphology of parthenogenetic conspectuses at GD 26 (unpublished data).

Because of rare report, it is difficult to compare the cloning efficiency of cloned KNP. The recipient-based cloning efficiency (No. of newborn piglets/No. of transferred cloned embryos) was $0.2-2.54 \%$ in MGH minipigs (Lai et al., 2002; Zhao et al., 2009; Hwang et al., 2013). In the present study, the cloning efficiency was ranged from 0.65 to $1.08 \%$ in KNP. It can be postulated that the recipientbased cloning efficiency was similar to other minipig species.

Taken together, it can be postulated that the methodological establishment of the production of SLA homotypedefined cloned KNP can be applied to the generation of transgenic cloned KNP as model animals for human disease and xenotransplantation.

\section{ACKNOWLEDGEMENTS}


Production of Cloned Korean Native Pig by Somatic Cell Nuclear Transfer

This work was carried out with the support of "Animal

Science \& Technology Development (Project No. PJ010 95601)" from Rural Development Administration, Republic of Korea. This study was supported by 2015 Postdoctoral Fellowship Program of National Institute of Animal Science, Rural Development Administration, Republic of Korea.

\section{REFERENCES}

Ahn KS, Kim YJ, Kim M, Lee BH, Heo SY, Kang MJ, Kang YK, Lee JW, Lee KK, Kim JH, Nho WG, Hwang S, Woo JS, Park JK, Park SB, Shim H (2011) Resurrection of an $\alpha$-1,3-galactosyltransferase genetargeted miniature pig by recloning using postmortem ear skin fibroblasts. Theriogenology 75:933-939.

Baguisi A, Behboodi E, Melican DT, Pollock JS, Destrempes MM, Cammuso C, Williams JL, Nims SD, Porter CA, Midura P, Palacios MJ, Ayres SL, Denniston RS, Hayes ML, Ziomek CA, Meade HM, Godke RA, Gavin WG, Overstrom EW, Echelard Y (1999) Production of goats by somatic cell nuclear transfer. Nat Biotechnol 17:456461.

Bazer FW, Spencer TE, Johnson GA, Burghardt RC, Wu G (2009) Comparative aspects of implantation. Reproduction 138: 195-209.

Betthauser J, Forsberg E, Augenstein M, Childs L, Eilertsen K, Enos J, Forsythe T, Golueke P, Jurgella G, Koppang R, Lesmeister T, Mallon K, Mell G, Misica P, Pace M, Pfister-Genskow M, Strelchenko N, Voelker G Watt S, Thompson S, Bishop M (2000) Production of cloned pigs from in vitro systems. Nat Biotechnol 18:10551059.

Bowen JA, Burghardt R (2000) Cellular mechanisms of implantation in domestic farm animals. Semin Cell Deve Biol 11: 93-104.

Chardon P, Renard C, Gaillard CR, Vaiman M (2000) The porcine major histocompatibility complex and related paralogous regions: a review. Genet Sel Evol 32:109128.

Cho HO, Ho CS, Lee YJ, Cho IC, Lee SS, Ko MS, Park C, Smith DM, Jeon JT, Lee JH (2010) Establishment of a resource population of SLA haplotype-defined Korean native pigs. Mol Cells 29:493-499.

Dehoux JP, Gianello P (2007) The importance of large animal models in transplantation. Front Biosci 12:48644880 .

Geisert RD, Brookbank JW, Roberts RM, Bazer FW (1982) Establishment of pregnancy in the pig: II. Cellular remodeling of the porcine blastocyst during elongation on day 12 of pregnancy. Biol Reprod 27:941-955.

Han X, Ouyang H, Chen X, Huang Y, Song Y, Zhang M, Pang D, Lai L, Li Z (2013) Aberrant expression of Igf2/H19 in porcine parthenogenetic fetuses and placentas. Anim Reprod Sci 139:101-108.

Hanekamp JS, Duran-Struuck R, Sachs DH (2011) Allotransplantation in miniature swine in genetics and immunology. In: McAnulty PA, Dayan AD, Ganderup NC, Hastings KL (eds.), The Minipig in Biological Research. CRC press, Boca Raton, FL, pp 357-372.

Hwang S, Oh KB, Kwon DJ, Ock SA, Lee JW, Im GS, Lee SS, Lee K, Park JK (2013) Improvement of cloning efficiency in minipigs using post-thawed donor cells treated with roscovitine. Mol Biotechnol 55:212-216.

Kato Y, Tani T, Sotomary Y, Kurokawa K, Kato J, Doguchi H, Yasue H, Tsunoda Y (1998) Eight calves cloned from somatic cells of a single adult. Science 282:2095-2098.

Kelley J, Walter L, Trowsdale J (2005) Comparative genomics of major histocompatibility complexes. Immunogenet 56:683-695.

Kim H, Chee HK, Yang J, Hwang S, Han KH, Kang J, Park JH, Kim JS, Lee SJ, Ock SA, Park MH, Park KS, Lee BC, Cho K, Noh J, Park W, Yun IJ, Ahn C (2013) Outcomes of alpha 1,3-GT-knockout porcine heart transplants into a preclinical nonhuman primate model. Trans- 
plant Proc 45:3085e3091.

Kim HJ, Son DS, Choi SH, Cho SR, Choe CY, Kim YG, Han MH, Ryu IS, Kim IC, Kim IH, Im KS (2005) Effects of cytochalasin B on parthenogenetic development of porcine follicular oocytes. Dev Reprod 9:49-52.

Kim KI, Lee JH, Li K., Zhang YP, Lee SS, Gongora J, Moran C (2002) Phylogenetic relationships of Asian and European pig breeds determined by mitochondrial DNA D-loop sequence polymorphism. Anim Genet 33:19-25.

Kim NE, Woo CJ, Choi HJ, Dirisala VR, Uhm SJ, Lee HT, Park C (2006) Discovery and analysis of new alleles of SLA-1 from Korean native pigs. Korean J Genet 28:356-360.

Kwiatkowski P, Artrip JH, John R, Edwards NM, Wang SF, Michler RE, Itescu S (1999) Induction of swine major histocompatibility complex class I molecules on porcine endothelium by tumor necrosis factor-alpha reduces lysis by human natural killer cells. Transplantation $67: 211-218$.

Lai L, Kolber-Simonds D, Park KW, Cheong HT, Greenstein JL, Im GS, Samuel M, Bonk A, Rieke A, Day BN, Murphy CN, Carter DB, Hawley RJ, Prather RS (2002) Production of alpha-1,3-galactosyltransferase knockout pigs by nuclear transfer cloning. Science 295:1089-1092.

Onishi A, Iwamoto M, Akita T, Mikawa S, Takeda K, Awata T, Hanada H, Perry ACF (2000) Pig cloning by microinjection of fetal fibroblast nuclei. Science 289:1188-1190.

Polejaeva IA, Chen SH, Vaught TD, Page RL, Mullins J, Ball S, Dai Y, Boone J, Walker S, Ayares DL, Colman A, Campbell KHS (2000) Cloned pigs produced by nuclear transfer from adult somatic cells. Nature 40:86-90.

Pope WF (1994) Embryonic mortality in swine. In: Geisert RD, Zavy MT, (eds), Embryonic Mortality in Domestic Species. CRC Press, Boca Raton, FL, pp. 53-77.

Shishido S, Naziruddin B, Howard T, Mohanakumar T (1997) Recognition of porcine major histocompatibility complex class I antigens by human CD8+ cytolytic T cell clones. Transplantation 64:340-346.
Spencer TE, Bazer FW (2004) Conceptus signals for establishment and maintenance of pregnancy. Reprod Biol Endocrinol 2:49.

Wilmut I, Schnieke AE, McWhir J, Kind AJ, Campbell KHS (1997) Viable offspring derived from fetal and adult mammalian cells. Nature 385:810-813.

Woo CJ, Choi JH, Kim NE, Park C (2006) Allelic variation and phylogenetic analysis of SLA-3 between Korean native pigs and other breeds. Korean J Genet 28:305-310.

Woo CJ, Kang IY, Yun HJ, Dirisala VR, Kim NE, Uhm SJ, Kim JH, Lee HT, Lee JH and Park CK (2005) Molecular cloning and analysis allelic variation of the SLA-2 gene in Korean native pigs. Korean J Genet 27:337-343.

Woo CJ, Kim J, Park K, Oh Y, Dirisala VR, Xiao R, Kim NE, Cho IC, Park C (2007) Characterization of DQB1 and DRB1 in Korean native pigs and the identification of three new DQB1 alleles. Korean J Genet 29:529-536.

Yeom HJ, Koo OJ, Yang J, Cho B, Hwang JI, Park SJ, Hurh S, Kim H, Lee EM, Ro H, Kang JT, Kim SJ, Won JK, O'Connell PJ, Kim H, Surh CD, Lee BC, Ahn C (2012) Generation and characterization of human heme oxygenase-1 transgenic pigs. PLoS One 7:e46646.

Zhao J, Ross JW, Hao Y, Spate LD, Walters EM, Samuel MS, Rieke A, Murphy CN, Prather RS (2009) Significant improvement in cloning efficiency of an inbred miniature pig by histone deacetylase inhibitor treatment after somatic cell nuclear transfer. Biol Reprod 81:525-530.

Zhu J, Harkness L, King T, Dobrinsky J, Fletcher J, Telfer E, Wilmut I, De Sousa PA (2000) Fetal development from parthenogenetically activated in vitro matured porcine oocytes. J Reprod Fertil Abstract Series 25:174.

Zhu J, King T, Dobrinsky J, Harkness L, Ferrier T, Bosma W, Schreier LL, Guthrie HD, DeSousa P, Wilmut I (2003) In vitro and in vivo developmental competence of ovulated and in vitro matured porcine oocytes activated by electrical activation. Cloning and Stem Cells 5:355-365. 